\title{
Variation of Cytokine Patterns Related to Therapeutic Response in Diffuse Cutaneous Leishmaniasis
}

\author{
Glória Bomfim, Cristiane Nascimento, ${ }^{*}$ Jackson Costa, $†$ Edgar M. Carvalho, \\ MANOEl BARRAL-NetTo,* AND Aldina BARRAL ${ }^{1}$
}

Serviço de Imunologia (HUPES-FAMED), Universidade Federal da Bahia, 41170-290 Salvador, Bahia, Brazil; *Centro de Pesquisas Gonçalo Moniz, FIOCRUZ, 40.295-001 Salvador, Bahia, Brazil; and †Departamento de Doença Infecciosas e

Parasitárias, Faculdade de Medicina, Universidade Federal do Maranhão, 65020 São Luis, Maranhão, Brazil

Bomfim, G., Nascimento, C., Costa, J., Carvalho, E. M., Barral-Netto, M., and Barral, A. 1996. Variation of cytokine patterns related to therapeutic response in diffuse cutaneous leishmaniasis. Experimental Parasitology 84, 188-194. Diffuse cutaneous leishmaniasis is a rare entity characterized by disseminated cutaneous nodules associated with specific anergy to leishmanial antigens. A low but not absent IFN- $\gamma$ expression by cells present in cutaneous lesions has been documented during the active phase of diffuse cutaneous leishmaniasis. In this study we confirm this observation, and extend it by showing a similar pattern in peripheral blood mononuclear cells and the variation of mRNA cytokine expression pattern during different stages of the disease. During active disease, patients did not express mRNA for IFN- $\gamma$, while expressing mRNA for IL-2, IL-4, and IL-10. In contrast, an expression of IFN- $\gamma$ and low IL-10 was observed after treatment-induced transient healing of cutaneous lesions. In three patients we have been able to analyze a third PBMC sample obtained after clinical relapse, documenting in all of them decreased IFN- $\gamma$ expression with no expression of IL-10. Although there was an association between the appearance of IFN- $\gamma$ expression and clinical improvement, with marked expression of IFN- $\gamma$ mRNA and decreased expression of mRNA for IL-10 after treatment, this was not sufficient to prevent relapse in these patients. Therefore, it is possible that factors other than the cytokines characteristic of the Th1 and Th2 balance are implicated in the inability of diffuse cutaneous leishmaniasis patients to mount an anti-Leishmania immune response causing clinical improvement. ๑) 1996 Academic Press, Inc.

INDEX DESCRIPTIONS AND ABBREVIATIONS: leishmaniasis; cytokines; therapy; cutaneous leishmaniasis; DCL, diffuse cutaneous leishmaniasis; IFN- $\gamma$, interferon-gamma; IL, interleukin; PBMC, peripheral blood mononuclear cells; DEPC, diethylpyrocarbonate; PCR, polymerase chain reaction.

\section{INTRODUCTION}

Human cutaneous leishmaniasis displays a spectral distribution, ranging from responsive mucosal leishmaniasis to the anergic form of diffuse cutaneous leishmaniasis (DCL), with localized cutaneous leishmaniasis (LCL) representing an intermediate state.

DCL is a rare manifestation, characterized by a selective lack of cell-mediated immunity against the parasite, resulting in extensive cutaneous involvement by nonulcerated nodules or plaques containing abundant parasites (Costa et al. 1992). DCL is a challenge to anti-parasite

${ }^{1}$ To whom correspondence and reprint requests should be addressed at Serviço de Imunologia, $3^{\circ}$ andar, Hospital Universitário Edgard Santos, Rua João das Botas s/n, Canela, SSA-Ba, Brazil. CEP 40.110.160. therapy. Following several anti-Leishmania therapeutic schemes, DCL patients exhibited clinical responses characterized by significant reduction of cutaneous lesions, but virtually all of them relapsed a few months after therapy (Costa et al. 1992).

Experimental studies showed that immune response against intracellular parasites seems to be mediated by two functional subpopulations of $\mathrm{CD}^{+}$cells, distinguished by their pattern of cytokine production (Th1 and Th2) (Yamamura et al. 1991; Romagnani 1992). In murine leishmaniasis, resistance has been associated with Th1-type reactions (production of IL-2 and IFN- $\gamma$ ) and susceptibility with Th2-type patterns (production of IL-4, IL-5, and IL-10) (Scott 1991; Cáceres-Dittmar et al. 1993).

Studies in human active DCL showed a con- 
sistent low expression of IFN- $\gamma$ and IL-2 mRNA associated with high IL-10, IL-5, and IL-4 mRNA in cells from cutaneous lesions (Pirmez et al. 1993).

In this study we took advantage of the possibility of investigating a relatively large group of DCL patients during different stages of the disease. Evaluation of the mRNA for IFN- $\gamma$, IL-2, IL-4, and IL-10 from PBMC was performed in a total of six DCL patients during active disease, and compared to the pattern obtained during transient healing; in three patients it was also possible to evaluate cytokine patterns after clinical relapse.

\section{Patients ANd Methods}

Patients. Six patients with DCL were evaluated in this study. They were treated with several anti-leishmanial regimens, including antimony gluconate, pentamidine, and amphotericin B. Clinical characteristics of the patients are presented in Table I. During their initial evaluation for this study, all patients exhibited active DCL, characterized by the presence of multiple nonulcerated nodules distributed in large areas of the body surface, and had been given antileishmanial drugs for at least 3 months. Further immunological evaluations were performed in six patients during clinical remission of their skin lesions and in three patients during relapse.

Lymphocyte separation and cell cultures. PBMC were obtained from heparinized venous blood layered over a Hypaque-Ficoll gradient (LSM; Organon Teknica Corporation, Durham, NC) as previously described (Horwitz et al. 1977). After washing three times in $0.9 \% \mathrm{NaCl}$, PBMC were resuspended in RPMI 1640 culture medium (GIBCO BRL, Grand Island, NY) supplemented with $200 \mathrm{IU} / \mathrm{ml}$ penicillin, $100 \mu \mathrm{g} / \mathrm{ml}$ streptomycin, and $10 \%$ type $\mathrm{AB}$ human sera. A total of $3 \times 10^{6}$ cells were cultured in microtiter plates (Falcon; Becton-Dickinson Co., Oxnard, CA) with or without $20 \mu \mathrm{g}$ of Leishmania antigen or phytohemagglutinin (PHA) (GIBCO; in a final dilution of 1:10). Cultures were maintained at $37^{\circ} \mathrm{C}$ in $95 \%$ air and $5 \% \mathrm{CO}_{2}$ for 3 days.

Measurement of cytokine secretion. Culture supernatants of antigen or PHA-stimulated PBMC were harvested after 24, 48, and $72 \mathrm{hr}$ of culture, and were analyzed by ELISA using a quantitative sandwich technique "Quantikine"' (RD Systems, Minneapolis, MN 55413) for IL-10 with the minimum detectable dose of $4.4 \mathrm{pg} / \mathrm{ml}$. Levels of IFN- $\gamma$ were measured by Cytoscreen immunoassay kit (BioSource International, Camarillo, CA 93012) with a minimum detectable dose of $<4 \mathrm{pg} / \mathrm{ml}$.

Preparation of cells for reverse transcriptase-polymerase chain reaction $(R T-P C R)$. PBMC at a concentration of $2 \times$ $10^{6}$ cells $/ \mathrm{ml}$ were kept nonstimulated or stimulated with 10 $\mu \mathrm{g} / \mathrm{ml}$ Leishmania antigen. At 24, 48, and $72 \mathrm{hr}$ of incubation cells were resuspended in $0.75 \mathrm{M}$ guanidium thiocyanate, sodium citrate, $\mathrm{pH} 7.0$, and $20 \%$ Sarcosyl and stored at $-70^{\circ} \mathrm{C}$.

Procedures to avoid nucleic acid contamination. Procedures were performed in three different rooms, separating preamplified samples from postamplified products. Gloves, tubes, and tips for pipettes used for RNA extraction and PCR were disposable. A special pipette set was used for RNA extraction and another for cDNA synthesis, and PCR reagents, including water, used in the PCR mixture were previously aliquoted to avoid repeated freezing and thawing. For each PCR analysis, one positive and one negative control were used. Between PCR tests all pipettes and racks were decontaminated by UV light and washed with $2 \%$ sodium hypoclorite.

RNA extraction. Total RNA was isolated from Leishmania antigen-stimulated PBMC at 24, 48, and $72 \mathrm{hr}$ of culture. Cells from $48 \mathrm{hr}$ of culture showed higher cytokine expression and are shown in this report. A phenolchloroform extraction of RNA was carried out following a standard protocol (Chomczynski and Sacchi 1987; Saiki et al. 1990) by adding $0.04 \mathrm{ml}$ of $2 M$ sodium acetate, $\mathrm{pH} 4.0$, $0.4 \mathrm{ml}$ of saturated phenol, and $0.2 \mathrm{ml}$ of chloroform:isoamyl alcohol at a 24:1 dilution. RNA was precipitated in $0.05 \mathrm{ml}$ of $3 \mathrm{M} \mathrm{NaAc}, \mathrm{pH} 7.0$, and $1 \mathrm{ml}$ of $95 \%$ ethanol, kept

TABLE I

Clinical Characteristics of Diffuse Cutaneous Leishmaniasis Patients

\begin{tabular}{cccccc}
\hline Patient & $\begin{array}{c}\text { Age } \\
\text { year/sex }\end{array}$ & $\begin{array}{c}\text { Duration of } \\
\text { disease in years }\end{array}$ & $\begin{array}{c}\text { Number of } \\
\text { cutaneous } \\
\text { lesions }\end{array}$ & $\begin{array}{c}\text { Transient } \\
\text { clinical } \\
\text { improvement }\end{array}$ & Relapse \\
\hline 1 & $28 / \mathrm{M}$ & 4 & $>500$ & Yes & No \\
2 & $31 / \mathrm{M}$ & 9 & 168 & Yes & Yes \\
3 & $16 / \mathrm{M}$ & 12 & 20 & Yes & Yes \\
4 & $16 / \mathrm{M}$ & 14 & 51 & Yes & Yes \\
5 & $21 / \mathrm{M}$ & 15 & 86 & Yes & Yes \\
6 & $12 / \mathrm{F}$ & 5 & 40 & & \\
\hline
\end{tabular}

Note. M, male; F, female. 
overnight at $-70^{\circ} \mathrm{C}$, later thawed and centrifuged for $20 \mathrm{~min}$ at $4{ }^{\circ} \mathrm{C}$. The pellet was dried at $37^{\circ} \mathrm{C}$ after two washings with $70 \%$ ethanol, and resuspended in DEPC-treated water. RNA concentration was determinated spectrophotometrically and its integrity evaluated through electrophoresis in $2 \%$ agarose gel.

Single-stranded cDNA synthesis. One microgram of total RNA was reverse transcribed by addition of 2.5 units of RNAsin (Promega, Madison, WI), 25 ng of oligo(dT)12-18 and $250 \mu M$ dNTPs (both from Pharmacia LKB Biotechnology, Piscataway, NJ), and 200 units of Moloney murine leukemia virus RNAse H-reverse transcriptase, $10 \mathrm{~m} M$ dithiothreitol, and $5 \times$ reverse transcriptase buffer (GIBCO BRL/Life Technologies Gaithersburg, MD) in a final reaction volume of $20 \mu \mathrm{l}$. The reaction was then incubated at $37^{\circ} \mathrm{C}$ for $1 \mathrm{hr}$ and boiled for $10 \mathrm{~min}$ after the addition of 180 $\mu \mathrm{l}$ of DEPC-treated water.

Polymerase chain reaction. Five microliters of 1:20 cDNA of each sample (after normalization to $\beta$-actin) were amplified by PCR for IL- 2 , IFN- $\gamma$, IL-4, and IL-10 in a 20- $\mu$ l mixture containing $200 \mu M$ dNTPs, $0.2 \mu M 3^{\prime}$ and 5' external primers, $2.25 \mathrm{mM} \mathrm{MgCl}{ }_{2}, 1 \times$ Gene Amp PCR buffer, and 1.25 units of AmpliTaq DNA polymerase (Perkin-Elmer/Cetus, Norwalk, CT). All reaction tubes included a 40- $\mu 1$ mineral oil overlay. A cDNA sample from a mixed lymphocyte culture from normal individuals was included as a positive control of cytokine expression for each PCR reaction. Cycling parameters for $\beta$-actin, IL-2, IFN- $\gamma$, and IL-4 amplifications were 30 cycles at the following temperatures: $94^{\circ} \mathrm{C}$ for $1 \mathrm{~min}, 60^{\circ} \mathrm{C}$ for $1 \mathrm{~min}, 72^{\circ} \mathrm{C}$ for 1 $\mathrm{min}$, and $30 \mathrm{sec}$, with a last cycle of $72^{\circ} \mathrm{C}$ for $2 \mathrm{~min}$. The amplification conditions for IL-10 consisted of 30 cycles of $94^{\circ} \mathrm{C}$ for $1 \mathrm{~min}, 60^{\circ} \mathrm{C}$ for $1 \mathrm{~min}$, and $72^{\circ} \mathrm{C}$ for $1 \mathrm{~min}$ and 30 sec in a thermal cycler reactor (National Labnet Company, Woodbridge, NJ). Cytokine-specific PCR was performed using oligonucleotide primers (kindly provided by Steve Reed) as previously described (Ehlers and Smith 1991). Sequences of external primers were as follows: $\beta$-actin, $5^{\prime}$ TGACGGGGTCACCCACACTGTGCCCATCTA and 5' CTAGAAGCATTGCGGTGGACGATGGAGGG (product size 661 bp); IFN- $\gamma$, 5' ATGAAATATACAAGTTATATCTTGGCTTT and 5' GATGCTCTTCGACCTCGAAACAGCAT (product size of $501 \mathrm{bp}$ ); IL-2, 5' ATGTACAGGATGCAACTCCTGTCTT and 5' GTCAGTGTTGAGATGATGCTTTGAC (product size of $458 \mathrm{bp}$ ); IL-4, 5' ATGGGTCTCACCTCCCAACTGCT and 5' CGAACACTTTGAATATTTCTCTCTCAT (product size of 456 bp); and IL-10, 5' TCTCAAGGGGCTGGGTCAGCTATCCCA and 5' ATGCCCCAAGCTGAGAACCAAGACCCA (product size of $351 \mathrm{bp}$ ). PCR products were separated on $1.5 \%$ agarose gels and transferred to Nytran (Schleicher and Schuell, Keene, NH) by Southern blotting.

Cytokine probes. Inserts from plasmids containing the human sequences IL-2, IL-4, IL-10, IFN- $\gamma$, and $\beta$-actin were isolated as described (Ghalib et al. 1993; De Waal et al. 1991). DNA fragments were excised from agarose gels, electroeluted, and purified as described (Sambrook et al.
1984). Probes were labeled with fluorescein using a random primer DNA labeling kit (ECL Amersham Life Science, Arlington Heights, IL).

Hybridization of amplified products by Southern blot. Hybridization was detected by ECL (ECL Amersham Life Science). Briefly, nylon membranes containing PCR products were incubated with fluoresceinated probes and washed three times at $56^{\circ} \mathrm{C}$ with antibody wash solution provided by the manufacturer. Antifluorescein peroxidase conjugate, diluted 1:1000, and the manufacturer's detection system were applied before film exposure for $10 \mathrm{~min}$.

\section{RESULTS}

Results are presented for each phase of the disease, i.e., the active, transient remission, and relapse phases. During the active phase of disease no patient exhibited detectable IFN- $\gamma$ mRNA. All patients exhibited signals of IL-2 mRNA although with varying different intensity. Four of the six patients had high expression of IL-4 mRNA, whereas all of them exhibited mRNA for IL-10 (Fig. 1, column A). In three patients $(1,3$, and 6$)$ the signal for IL-10 mRNA was very intense and in the other patients much weaker. Strong IL-10 mRNA signals did not always coincide with intense signal for IL-4, since patients 2 and 5 had little IL-10 mRNA and a very strong signal for IL-4 mRNA. Patient 3 had intermediate signal for IL-4 and a very intense signal for IL-10.

High IFN- $\gamma$ mRNA expression was observed during the transient healing phase in all but patient 1 . In contrast, significant reductions during the transient healing period were observed in IL-10 mRNA. On the other hand, there were no changes for IL-4 mRNA expression in the majority of patients evaluated. It is noteworthy that patient 1 had clinical remission with market reduction of IL-10 without alteration in other cytokine signals (Fig. 1, column B).

During active disease the majority of patients showed very intense mRNA expression for IL4 , except for patients 3 and 4 . A high expression of IL-4 mRNA was observed during healing phase. Only patient 6 had very weak expression of IL-4 mRNA during healing phase of the disease.

Relapse of cutaneous lesions was documented in three of six patients during the period 
IFN- $\gamma$
A

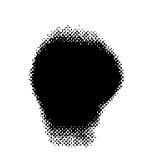

B

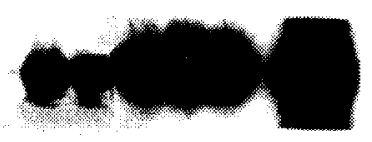

\section{$\begin{array}{llllllllllllll}1 & 2 & 3 & 4 & 5 & 6 & C+ & 1 & 2 & 3 & 4 & 5 & 6 & C+\end{array}$}

IL-2

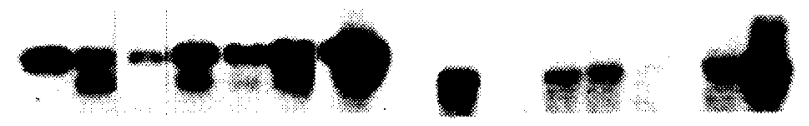

\section{$\begin{array}{llllllllllllll}1 & 2 & 3 & 4 & 5 & 6 & C+ & 1 & 2 & 3 & 4 & 5 & 6 & C+\end{array}$}

IL-10
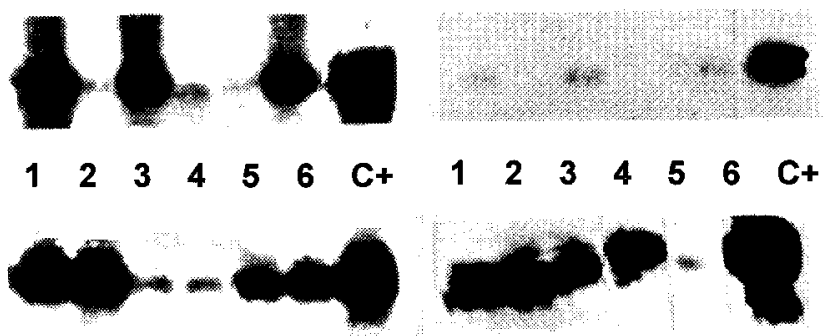

IL-4
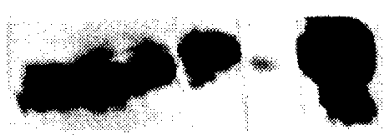

$\begin{array}{lllllll}1 & 2 & 3 & 4 & 5 & 6 & C+\end{array}$

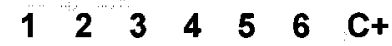

$\beta$-actin
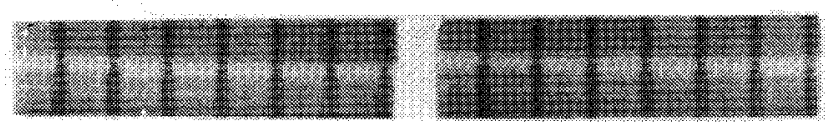

$\begin{array}{lllllll}1 & 2 & 3 & 4 & 5 & 6 & C\end{array}$

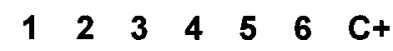

FIG. 1. Cytokine patterns in diffuse cutaneous leishmaniasis. Peripheral blood mononuclear cells from six patients with active DCL were evaluated by RT-PCR for cytokines. (A) Cytokine expression during active disease, before treatment; (B) cytokine expression during clinical remission of cutaneous lesions, after treatment.

Numbers 1 to 6 are patients; $\mathrm{C}+$ is a positive control of cytokine expression by PCR.

of observation (patients 4, 5, and 6). Patient 6 had a significant decrease in IFN- $\gamma$ mRNA expression, whereas patients 4 and 5 continued to show intermediate signals for this cytokine during relapse (Fig. 2). All patients showed a marked reduction of IL-10 mRNA expression at the beginning of the relapse phase. Strong IL-4 mRNA expression was observed in patient 6 , while very little message was seen in patients 4 and 5. There was an inverted cytokine pattern for IFN- $\gamma$ and IL-10 mRNA expression during active and relapse phases in DCL patients.

Cytokine levels were determined by ELISA in supernatants from patients' lymphocytes stimulated with Leishmania antigen or PHA. High levels of IL-10, but not IFN- $\gamma$, were de- tected in active DCL patients following antigenstimulation (Tables II and III). Immediately after clinical remission IFN- $\gamma$ levels increased, and IL-10 was not detectable. Except for patients 5 and 6 , this pattern of cytokine production paralleled the findings of cytokine mRNA detection by PCR.

\section{DisCUSSION}

The results presented in this report provide the first evidence for a change in cytokine pattern, in the same patients, in correlation with disease status in DCL. Recently, transient alterations in immune reactivity, as assessed by lymphocyte proliferation and antibody response, have been documented after ivermectin treat- 


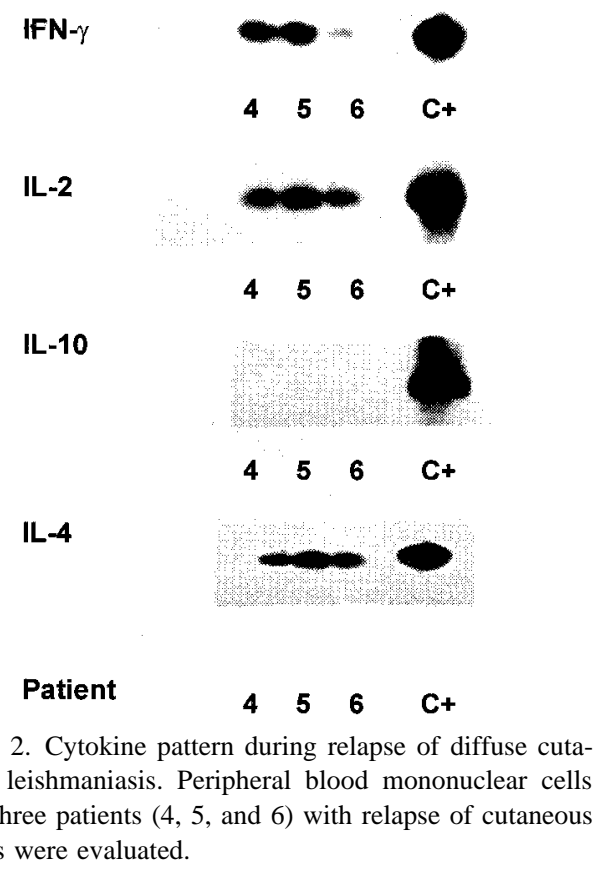

ment of onchocerciasis (Steel et al. 1994) and these changes may be due to modification of antigen load. Our findings show that some cytokines, mainly IFN- $\gamma$ mRNA and IL-10, have a pattern coinciding with clinical changes in human leishmaniasis. The absence of IFN- $\gamma$ mRNA during the active phase of disease was followed months later, after a favorable therapeutic response, by an increase of mRNA expression and production of IFN- $\gamma$ on the supernatant of antigen-stimulated cells. Interestingly, in only one of six patients in this study, a direct

TABLE II

Levels of IFN- $\gamma(\mathrm{pg} / \mathrm{ml})$ in PBMC Supernatant

\begin{tabular}{clcr}
\hline \multirow{2}{*}{ Patient } & \multicolumn{1}{c}{$\begin{array}{c}\text { Clinical } \\
\text { condition }\end{array}$} & $\begin{array}{c}\text { Leishmanial } \\
\text { antigen }\end{array}$ & PHA \\
\hline 2 & Before therapy & $<$ limit & 992 \\
\multirow{2}{*}{3} & After therapy & 49 & 1200 \\
& Before therapy & $<$ limit & 1200 \\
4 & After therapy & 20 & NP \\
& Before therapy & $<$ limit & 1181 \\
& After therapy & 46 & NP \\
\hline
\end{tabular}

Note. PHA, phytohemagglutinin; PBMC, peripheral blood mononuclear cells; NP, not performed; <limit, lower than minimum detectable dose.
TABLE III

Levels of IL-10 (pg/ml) in PBMC Supernatant

\begin{tabular}{cll}
\hline Patient & \multicolumn{1}{c}{$\begin{array}{c}\text { Clinical } \\
\text { condition }\end{array}$} & $\begin{array}{c}\text { Leishmanial } \\
\text { antigen }\end{array}$ \\
\hline 1 & $\begin{array}{l}\text { Before therapy } \\
\text { After therapy }\end{array}$ & $\begin{array}{l}855 \\
<\text { limit }\end{array}$ \\
4 & Before therapy & 535 \\
& After therapy & $<$ limit \\
5 & Before therapy & 550 \\
& After therapy & $<$ limit \\
6 & Before therapy & 100 \\
& After therapy & $<$ limit \\
\hline
\end{tabular}

Note. PBMC, peripheral blood mononuclear cells; <limit, lower than minimum detectable dose.

correlation between cutaneous lesion healing and IFN- $\gamma$ mRNA signal was not observed (patient 1). The role of IFN- $\gamma$ is questionable, however, considering that its presence did not prevent relapse. Cytokines do not act as isolated molecules, and the relative amounts of other products that potentiate or neutralize their action are of utmost importance in understanding the final result. It is possible that the marked decrease in IL-10 potentiates the effect of locally produced IFN- $\gamma$.

Experimentally IL-10 has been implicated in inhibiting cytokine production by Th1 cells (Fiorentino et al. 1991). IL-4 (Nabors and Farrel 1994) and TGF- $\beta$ have also been shown to counterbalance the IFN- $\gamma$ effect, whereas IL-12 stimulates IFN- $\gamma$ production. It is possible then that cytokines not evaluated in the present study may also have influenced the course of disease. Production of IFN- $\gamma$ by cells obtained from cutaneous lesions in DCL has been shown (Cáceres-Dittmar et al. 1993) concomitant with a high expression of IL-4, IL-5, and IL-10. A predominance of IL-4 expression was also reported in lesions from DCL patients from Brazil (Pirmez et al. 1993). The clinical and therapeutic status of these patients at the time of biopsy were not given clearly. In our study we found a predominance of IL-10 and IL-4, with no expression of IFN- $\gamma$ and variable expression of IL-2 mRNA.

Despite small differences, the present observation made with $\mathrm{PBMC}$ reflected the general 
pattern observed in studies using cells obtained from lesions (Cáceres-Dittmar et al. 1993; Pirmez et al. 1993). The single cytokine that best reflected disease status was IFN- $\gamma$ which was absent during active disease or relapse, and positive during remission of clinical manifestations. We cannot, from the present findings, attribute a major protective role to this cytokine, since even in the presence of IFN- $\gamma$, patients experienced relapses. IL-10 was highly expressed during active DCL, with a marked reduction of expression during clinical improvement in most but not all patients. IL-10 may play a crucial role in the disease status, suppressing IFN- $\gamma$ action, considering its powerful suppressive action in the skin (Berg et al. 1995).

Dissociation between the production of IL-2 and IFN- $\gamma$ during active disease was an important finding in all patients in the present study. At this stage, all patients exhibited mRNA for IL-2, but not for IFN- $\gamma$. A similar finding had been reported in murine leishmaniasis (Scott 1991). The contrary situation, IFN- $\gamma$ in the absence of message for IL-2, has also been reported in human leishmaniasis in lesions from DCL (Cáceres-Dittmar et al. 1993) and in LCL (Melby et al. 1994). Differences in antigen signaling and cell responses may be involved in this dissociation. Another possibility is that different cell sources are involved in the production of these cytokines. NK cells are able to produce IFN- $\gamma$ (Kos and Engleman 1996) and B cells may be a source for IL-2.

In the present study, in only two cases, an elevated expression of IL-10 was accompanied by high IL-4 expression, showing that different patients may use diverse immunomodulatory mechanisms even in a highly selected group of patients with similar anergic disease. Such findings indicate that strategies of immune intervention have to be individually tailored.

\section{ACKNOWLEDGMENTS}

We are grateful to Drs. Franklin Neva and Allen Cheever for critically reviewing the manuscript, and to Dr. Steve Reed for primer design. This work was supported by NIH Grant A130639. Drs. Manoel Barral-Netto and Aldina Barral are Senior Investigators of the Brazilian National Research Council (CNPq).

\section{REFERENCES}

Barral, A., Pedral-Sampaio, D., Grimaldi, G., Momen, H., McMahon-Pratt, D., Jesus, A. R., Almeida, R., Badaró, R., Barral-Netto, M., Carvalho, E. M., AND Johnson, W. D., JR. 1991. Leishmaniasis in Bahia: Evidence that Leishmania amazonensis produces a wide spectrum of clinical disease. American Journal of Tropical Medicine and Hygiene 44, 536-546.

Berg, D. J., Leach, M. W., Kuhn, R., Rajewsky, K., Muller, W., Davidson, N. J., AND RenNiCK, D. 1995. Interleukin 10 but not interleukin-4 is a natural suppressant of cutaneous inflammatory responses. Journal of Experimental Medicine 182, 99-108.

Cáceres-Dittmar, G., Tapia, F. J., SAnchez, M. A., Yamamura, M., Uyemura, K., Modlin, R. L., Bloom, B. R., AND Convit, J. 1993. Determination of the cytokine profile in American cutaneous leishmaniasis using the polymerase chain reaction. Clinical Experimental Immunology 91, 500-505.

Costa, J. M. L., Saldanha, A. C. R., Melo e Silva, A. C., Neto, A. S., Galvão, C. E. S., Pedroso E Silva, C. M. O., AND Silva, A. R. 1992. Estado atual da leishmaniose cutânea difusa (LCD) no Estado do Maranhão. II. Aspectos epidemiológicos, clinico-evolutivos. Revista da Sociedade Brasileira de Medicina Tropical 25, 115123.

De Waal Malefyt, R., Abrams, J., Bennet, B., Frigdor, C. G., AND DE VRIES, J. E. 1991. Interleukin-10 (IL-10) inhibits cytokine synthesis by human monocytes: An autoregulatory role of IL-10 produced by monocytes. Journal of Experimental Medicine 174, 1209.

EhLERS, S., AND SMith, K. A. 1991. Differentiation of T cell lymphokine gene expression: The in vitro acquisition of $\mathrm{T}$ cell memory. Journal of Experimental Medicine 173, 25.

Fiorentino, D. F., Zlotnik, A., Vieira, P., Mosmann, T. R., Howard, M., Moore, K. W., and O'Garra, A. 1991. IL-10 acts on the antigen-presenting cell to inhibit cytokine production by Th1 cells. Journal of Immunology 146, 3444-3451.

Ghalib, H. W., Piuvezam, M. R., Sheiky, Y. A. W., SidDig, M., Hashim, F. A., El-Hassan, A. M., Russo, D. M., AND REED, S. G. 1993. Interleukin 10 production correlates with pathology in human Leishmania donovani infections. Journal of Clinical Investigations 91, 1644.

Horwitz, D. A., AND Garret, M. A. 1977. Distinctive functional properties of human blood L lymphocytes: A comparison with $\mathrm{T}$ lymphocytes, B lymphocytes and monocytes. Journal of Immunology 118, 1712.

Kos, F. J., AND ENGLEMAN, E. G. 1996. Immune regulation: A critical link between NK cells and CTLs. Immunology Today 17, 175-176.

Melby, P. C., Andrade-Narvaez, F. J., Darnell, B. J., Valencia-Pacheco, G., Tryon, V. V., and PalomoCetinA, A. 1994. Increased expression of proinflamma- 
tory cytokines in chronic lesions of human cutaneous leishmaniasis. Infection and Immunity 62, 837-842.

Murphy, E., Hieny, S., Sher, A., ANd O'Garra, A. 1993. Detection of in vivo expression of interleukin-10 using a semi-quantitative polymerase chain reaction method in Shistosoma mansoni infected mice. Journal of Immunology Methods 162, 211-223.

Nabors, G. S., And Farrell, J. P. 1994. Depletion of interleukin-4 in Balb/c mice with established Leishmania major infections increases the efficacy of antimony therapy and promotes Th1-like responses. Infection and Immunity 62, 5498-5504.

Pirmez, C., Yamamura, M., Uyemura, K., Paes-Oliveira, M., Conceição-Silva, F., And Modlin, R. L. 1993. Cytokine patterns in the pathogenesis of human leishmaniases. Journal of Clinical Investigation 91, 1390-1395.

RoMAGNANI, S. 1992. Induction of TH1 and TH2 responses: A key role for the "natural", immune response? Immunology Today 13, 379-381.

Romagnani, S. 1995. Biology of human Th1 and Th2 cells. Journal of Clinical Immunology 15, 121-129.

SAIKI, R. K. 1990. Amplification of genomic DNA. In
"'PCR Protocols", (M. A. Inins, D. H. Gelfand, J. J. Sninsky, and T. J. White, Eds.), pp. 13-20. Academic Press, San Diego.

Sambrook, J., Fritsch, E. F., And Maniatis, T. 1989. “'Molecular Cloning: A Laboratory Manual.' Cold Spring Harbor Laboratory Press, Cold Spring Harbor, NY.

ScOTT, P. 1991. IFN- $\gamma$ modulates the early development of Th1 and Th2 responses in a murine model of cutaneous leishmaniasis. Journal of Immunology 147, 3149-3155.

Steel, C., Lujan-Trangay, A., Gonzalez-Peralta, C., ZeA-Flores, G., AND Nutman, T. B. 1994. Transient changes in cytokine profiles following ivermectin treatment of onchocerciasis. Journal of Infectious Disease 170, 962-970.

Yamamura, M., Uyemura, K., Deans, R. J., Weinberg, K., Rea, T. H., Bloom, B. R., AND Modlin, R. L. 1991. Defining protective responses to pathogens: Cytokine profiles in leprosy lesions. Science 254, 277-279.

Received 20 May 1996; accepted with revision 12 August 1996 